that resist pests because their genome incorporates genes from Bacillus thuringiensis (Bt) — a naturally occurring organism and others genetically engineered to tolerate Monsanto's Roundup weedkiller, the St Louis corporation has led a sometimes-sceptical world into a new age of genetically modified crops.

David Fischhoff, Monsanto's director of advanced genomics, expects systematic bioprospecting to play a larger role in future. "When we started developing resistant crops, the world had at its disposal a few hundred genes," he says. "For agricultural purposes, we had a handful of them - and out of that, Monsanto has started some very successful projects.

"We're now about to have some understanding of literally tens of thousands of genes," he adds. "Bioprospecting for genes will become more important than bioprospecting for proteins and organisms has been in the past."

\section{Need for dialogue}

An equally broad array of opportunities could exist in the use of genes from natural products to modify foodstuffs to enhance human health, says Ganesh Kishore, co-president of Monsanto's nutrition branch. Kishore envisages the discovery of natural genes that can be added to foods such as cooking oil, and so reinstated in the food chain.

But the Indian-born scientist has a warning for his former compatriots: "When I harness a gene, the fruits of the work are for everybody - but the person who developed it was me," he asserts. Like others involved, Kishore is deeply concerned about the state of relations between the rich and poor nations on this topic. He says the parties haven't struck up the right conversation because "there has been a polarization, and we've ended up arguing over who is in the wrong."

Kishore says that Monsanto will "put its best foot forward" to make arrangements with countries such as India. But the Missouri life sciences corporation knows that it can expect to encounter a great deal of suspicion as it seeks to extend its leadership position in agricultural biotechnology (see Nature 388, 817 \& 389, 534; 1997), and Kishore's stance on property rights is unlikely to go down well in developing countries.

The gap between what the developed world wants from biodiversity, and what the developing world thinks it should retain for itself, seems to be widening. Tensions between the two sides seem unlikely to relax in the near future.

\title{
Old scores surface as African states face new opportunities
}

[LONDON] Feelings about 'bioprospecting' run high in Africa. The opposition is based partly on memories of colonial times, when areas of the continent were used as a free source of plants by staff from colonial powers' botanic gardens. But there are signs that this historical antagonism is beginning to soften, and that a pragmatism based on self-interest is starting to emerge.

The antagonism is still present. At the end of last month, a task force from the Organization of African Unity (OAU) put the finishing touches to a draft model bill on "community rights and access to biological resources".

The draft, heavily influenced by Ethiopia and the OAU's science commission, seeks to penalize those engaged in bioprospecting without permission from governments. More controversially, it refuses to recognize patents on compounds based on natural products, unless the patent recognizes the 'ownership' and contribution of indigenous peoples (see Nature 392, 423; 1998).

The draft will be circulated to the OAU's 53 member states, to be discussed at a meeting in June. It is designed as a template for legislation in individual African states.

Its origins lie in a meeting of African ministers in 1993. This meeting decided to ban all bioprospecting by overseas organizations until Africa-wide legislation was put in place. But the intervening five years have seen a change in thinking, a new pragmatism, and a breaking of ranks.

Many individual African states say that while they support strong legislation in principle - as they still find it difficult to trust bioprospecting initiatives from former colonial rulers - they do not believe this should stop them negotiating deals from which they stand to benefit.

The states are also more relaxed about the

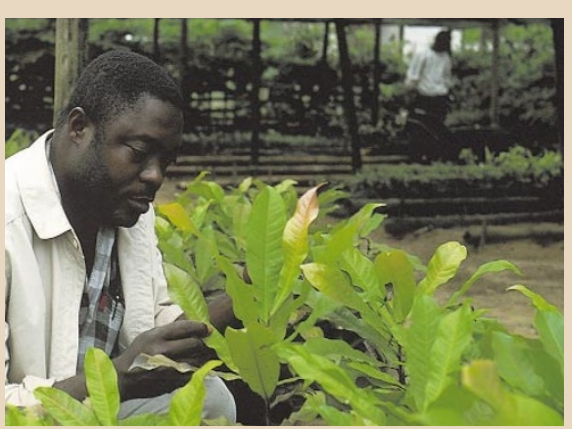

Plant power: growing Ancistrocladus korupensis, a potential anti-cancer drug, in Cameroon.

patents issue. They realize that the financial rewards from drug development are longterm and not guaranteed, particularly as it can take 10 years for a drug to come to market and only 3 per cent of drugs that undergo development stand a chance of commercial success. These countries are looking for other kinds of benefits.

Nigeria, Ghana, Tanzania, and Guinea are among those countries that have taken such a pragmatic stance.

Cameroon is hesitating. It has blocked at the last minute a proposed agreement to allow the US National Cancer Institute to study the forest vine Ancistrocladus korupensis, a promising anti-HIV agent, in August 1993. But the state has allowed universities to take part in another project sponsored by the US government.

Ethiopia, in sharp contrast, remains opposed to both bioprospecting and patenting. Ethiopia's stance is significant. It was once a colonial power in its own right, and its historical influence lingers in Africa.

Nigeria and Cameroon have become part of a bioprospecting network, the International Cooperative Biodiversity Groups (ICBG), which was set up and sponsored by the US government. The network's African arm includes two US research institutions and 13 in Nigeria and Cameroon.

The ICBG aims to find plants from Africa's forests that could provide drugs to treat priority diseases in the United States such as AIDS, cancer, and disorders of the cardiovascular and central nervous systems. In return, the host country is promised financial remuneration, as well as a range of benefits such as a boost for local research capacity and spin-off benefits for traditional medicine.

The sponsors promise that patent applications will include the names of all possible contributors to the invention including scientists, local communities and traditional healers.

But for Ethiopia and the OAU's scientific commission, these promises are not enough. According to Johnson Ekpere, executive secretary of the OAU's Scientific and Technological Research Commission, a bioprospecting arrangement must find an alternative to patenting.

Ekpere says he is sympathetic to the aims of the ICBG. But he believes another method has to be found to balance the desire to protect an invention with what he describes as a country's "right" to safeguard the sovereignty of its natural products, and to provide shared and free access to an organism.

But Maurice Iwu of ICBG Africa argues that the ability to patent is integral to the concept of bioprospecting. He says that no overseas partner will engage in bioprospecting unless the results of research can be protected in a patent. Iwu says the ICBG's patenting proposals are designed to "be of maximum benefit" to the host country.

Ehsan Masood 